\title{
Impact of Selected Structural, Material and Exploitation Factors on Adhesive Joints Strength
}

\author{
Anna Rudawska $^{1}$, Marek Maziarz ${ }^{1}$, and Izabela Miturska ${ }^{1 *}$ \\ ${ }^{1}$ Lublin University of Technology, Faculty of Mechanical Engineering, Department of Production Engineering, Nadbystrzycka 36, \\ 20-618 Lublin
}

\begin{abstract}
Adhesive bonding is currently one of the most popular techniques of joining different materials. It is worth noting that this process is more and more often used in several industries: automotive, transport, mechanical engineering, medicine, electronics, light industry, as well as many others. The present article is aimed at determining an impact of selected structural, material and exploitation factors on adhesive bonds' strength. Strength tests were carried out on adhesive connections of pine wood. An exploitation factor under analysis was resistance to different temperature values both positive and negative. Six different variants of a bonds' seasoning temperature value were used. Another variable factor was a structure of bonds, i.e. adhesive butt joints and adhesive half lap joints. Also, two types of adhesives were used: one of them was dedicated to wooden elements bonding, whereas the second one was a two-component adhesive composition based on epoxide resin. Strength tests described in the present article showed substantial impact of selected structural, material and exploitation factors on the adhesive bonds' strength.
\end{abstract}

\section{Introduction}

Boding is a crucial process in engineering. Nowadays there are many ways of bonding materials, which can be divided into separable and inseparable ones. The difference between them is that separable bonding enables mounting and dismounting of elements at any time without damaging them, while in case of inseparable bonding it is necessary to damage components that bond elements [1-4]. A perfect example of inseparable bonding is adhesion. This technique uses adhesive as a necessary agent to obtain a durable joint. Adhesion is one of the oldest techniques of joining materials. It was developed in 1940 when it was used for the first time in aviation [5-9].

The strength of adhesive bonds depends on numerous factors: structural, material and exploitation ones. Among basic structural factors having considerable impact on the adhesive bonds' strength, the most vital one is a type of the bond structure [10,11]. Adhesive bonds may be of different shapes, which is demonstrated with an example of butt and lap joints. Structural factors also include joined elements thickness and the lap length. Technological factors, in turn, include a method of surface preparation, temperature, pressure and curing time. Material factors also play a vital role. They include, among others, type and characteristics of the material and type of adhesive. The last group of factors impacting the adhesive joints' strength are exploitation ones. These are the conditions in which the adhesive bonds are exploited. An example of such factor may be temperature that acts on the adhesive bonds for a determined period $[12,13]$.

The aim of this article is to conduct strength tests and, based on their result, determine the impact of selected structural, material and exploitation factors on the adhesive bonds' strength. Two types of adhesivebonded joints were subject to tests: butt adhesive joints and half lap adhesive joints, where joined elements were made of pine wood. Two types of adhesives were used: Prefere 6312 and epoxide adhesive composition. An exploitation factor under analysis was resistance to temperature. Six different variants of temperature values in which the adhesive bonds were being seasoned were used.

\section{Research Methodology}

Wood is a popular material often used for finishing. It also found a wide use in furniture production and construction for joining wooden structures. Wooden toys or decor elements are also popular [14].

Adhesive bonding of wood is a relatively fast and cheap process. Its biggest advantage is a possibility to create multilayer wooden constructions of various, often surprising forms. Bonding agents, in this case adhesivebonded joints, are invisible in contrary to the traditional bonding with use of nails or screws. Adhesive may also serve as a complement to other type of bonding, e.g. with use of pegs. Reinforcement of bonds with use of adhesive makes construction more durable and resistant to mechanical damage [15].

*Corresponding author: i.miturska@ pollub.pl 
Adhesive-bonded joints of wooden elements described in the article were subject to strength tests.

\subsection{The Bonded Material's Characteristics}

Material used in the tests included samples of one of the most popular types of pine, i.e. common pine.

Common pine has a great economic meaning in Poland as it provides valuable timber, which is used in carpentry, furniture making or serves as furnace fuel. The best timber is the one made of trees aged approx. 100 years, as it is relatively light, easy to process and resinous. Common pine wood is divided into sapwood and heartwood (Fig. 1). Sapwood is of yellowish colour, whereas heartwood is red-brown and yellows with time. When analysing a common pine structure, it is worth noting that rings of a young tree are lighter than those of an old one, thanks to which it is possible to estimate its age. Moreover, common pine is characterised by a very intense resinous smell. Physicochemical characteristics of common pine are presented in Table 1 .

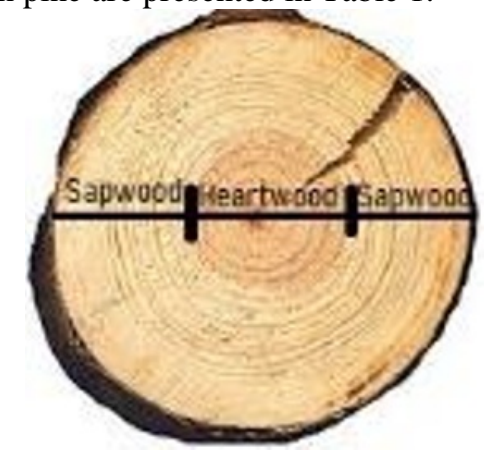

Fig. 1. Cross-section of a common pine.

Table 1. Physicochemical characteristics of pine [3].

\begin{tabular}{|c|c|}
\hline Characteristic & Value \\
\hline bending strength & $41-100-205 \mathrm{MPa}$ \\
\hline compressive strength & $35-55-94 \mathrm{MPa}$ \\
\hline tensile strength along the grain & $35-104-196 \mathrm{MPa}$ \\
\hline cross-grain tensile strength & $1.0-3.0-4.4 \mathrm{MPa}$ \\
\hline dry density & $300-490-860 \mathrm{~kg} / \mathrm{m} 3$ \\
\hline wet density $12-15 \%$ & $330-510-890 \mathrm{~kg} / \mathrm{m} 3$ \\
\hline density after felling & $750-820-850 \mathrm{~kg} / \mathrm{m} 3$ \\
\hline impact strength & $1.5-4.0-13.0 \mathrm{~J} / \mathrm{cm} 2$ \\
\hline $\begin{array}{c}\text { Brinell hardness on the } \\
\text { longitudinal plane }\end{array}$ & $25-40-72 \mathrm{MPa}$ \\
\hline $\begin{array}{c}\text { Brinell hardness on the transverse } \\
\text { plane }\end{array}$ & $13-19-24 \mathrm{MPa}$ \\
\hline
\end{tabular}

a)

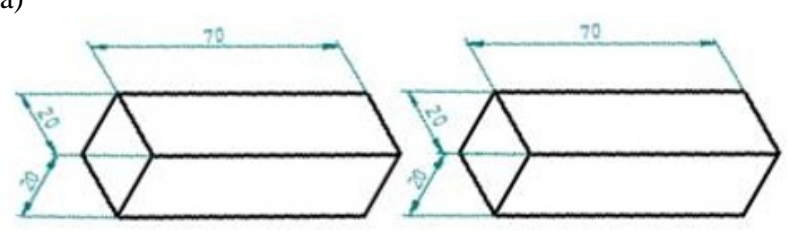

b)

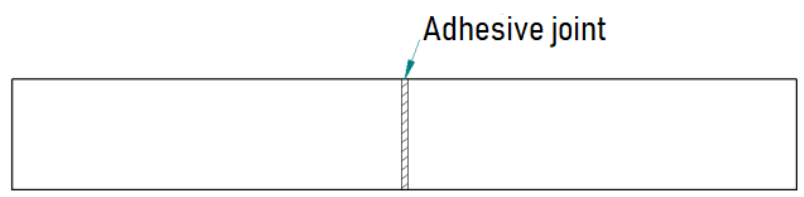

Fig. 2. Butt joint: a) samples' dimensions, b) joint's scheme.

\subsection{Adhesive-bonded joints}

To conduct strength tests, 480 samples made of pine wood were prepared. 240 adhesive bonded-joints were created, including 120 adhesive butt joints and 120 adhesive half lap joints. Dimensions of samples and schemes of joints are presented in Figures 2 and 3.

a)

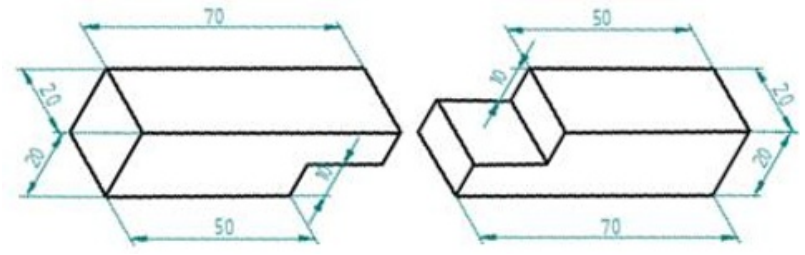

b)

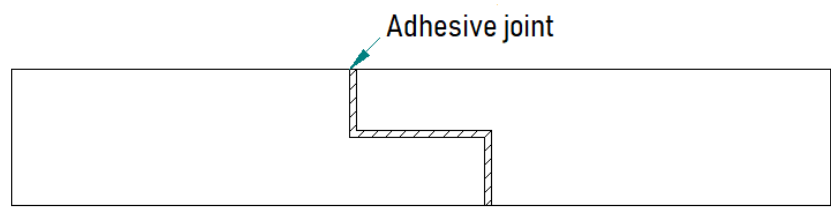

Fig. 3. Half lap joint: a) samples' dimensions, b) joint's scheme.

\subsection{Adhesives}

Two types of adhesives were used: Prefere 6312 and epoxide adhesive composition made of epoxy resin Epidian 57 and TFF curing agent.

\subsubsection{Prefere 6312}

Prefere 6312 is a single-component adhesive for wood. However, sometimes it is also used for other materials, e.g. bonding wood with metal. Such solutions, though, often cause corrosion because Prefere 6312 is acidic - its $\mathrm{pH}$ varies between 2.8 and 3.2, which causes reaction with metal and may lead to undesirable discolouration of adhesive joints. Prefere 6312 is widely applied to assembly processes with use of wooden components, e.g. wood panels bonding, laminating or lap joining. Moreover, this adhesive was water resistance-tested, is in class D3 and is characterised by high thermal resistance. Viscosity range is $15,000 \pm 3,000 \mathrm{MPa} \cdot \mathrm{s}$ [16]. The adhesive's life is about 6 months, provided it is stored in appropriate conditions. The adhesive layer should be about $100-200 \mathrm{~g} / \mathrm{m}^{2}$ but it mostly depends on the surface, material type and its absorptivity. Prefere 6312 gets the initial strength just after 6-7 minutes at about $20^{\circ} \mathrm{C}$. A factor that is necessary for curing processes is pressure which value should be between $0.2-0.6 \mathrm{~N} / \mathrm{mm}^{2}\left(2-6 \mathrm{kP} / \mathrm{cm}^{2}\right)$. As a consequence of such pressure, the adhesive is usually squeezed out of the joint, which provides information whether the pressure value is appropriate. The pressure time should be between 5-10 min. Prefere 6312 gets its highest strength after 24 hours.

\subsubsection{Adhesive composition E57/TFF/100:22}

The main ingredient of an adhesive composition used in tests is Epidian 57 in a form of viscous liquid of yellowish to light-brown colour. Resin's density at $20^{\circ} \mathrm{C}$ is $1.14-1.17 \mathrm{~g} / \mathrm{cm}^{3}$, while at $25^{\circ} \mathrm{C}$ it is $13,000-19,000$ 
$\mathrm{MPa} \cdot \mathrm{s}$ [17]. Epidian 57 dissolves in alcohols, ketones, esters, aromatic hydrocarbons. It does not dissolve in water. As far as an application is concerned, this resin may be used as an ingredient of adhesives for cold gluing of metal, glass, leather, polymers and wood. It is necessary to add curing agent in appropriate proportions to the resin. Thanks to this the processes such as adhesive crosslinking and curing processes may occur. In this composition the TFF curing agent was used. It is used for curing processes of epoxide compositions dedicated for construction works where air humidity is high, and temperature is relatively low. The TFF curing agent viscosity at $25^{\circ} \mathrm{C}$ is up to $10000 \mathrm{MPa} \cdot \mathrm{s}$, whereas at $20^{\circ} \mathrm{C}-1.15-1.20 \mathrm{~g} / \mathrm{cm}^{3}$. To prepare the adhesive, epoxy resin was mixed with the TFF curing agent in a recommended stoichiometric amount, in a proportion 100:22, i.e. 22 grams of curing agent to 100 grams of epoxy resin. In such proportion break tensions' values are about 50 to $50 \mathrm{MPa}$. Bending strength varies between 80 to $90 \mathrm{MPa}$, whereas compressive strength is about 55 $\mathrm{MPa}$.

Due to high reactivity of the TFF curing agent, the mixture of resin and curing agent was prepared directly before use in the proportions possible to be used within a few minutes.

\subsection{Conditions of making joints}

Before adhesion process was carried out, the samples surface was grinded with sandpaper of 180 grit. Then, it was cleaned to remove wood filings and dust.

Directly before adhesion process the adhesive was applied manually on elements to be joined with use of a brush. After that samples were joined together. After putting initial pressure, excess of adhesive was removed, and samples were fixed in a specially prepared arranging-fixing device (Fig. 4), thanks to which it was also possible to put constant pressure during curing process.

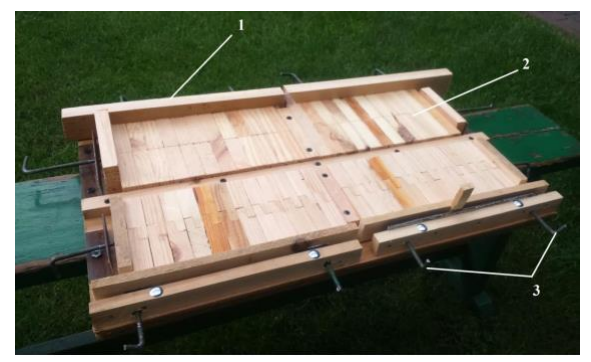

Fig. 4. Scheme of an arranging device for putting pressure and fixing: 1 - wooden wall of a device, 2 - adhesive joints, 3 compression bolt.

According to the recommendations of both adhesives' producers, the curing process should last 24 hours to obtain the best binding properties possible. In the present case the curing time was 48 hours to make sure that the adhesive joints have been hardened completely. Compression force of compression bolts was $250 \mathrm{MPa}$. The process of making and hardening all adhesive joints was at $22^{\circ} \pm 2{ }^{\circ} \mathrm{C}$ and relative air humidity $33 \pm 2 \%$.

\subsection{Seasoning conditions}

The aim of the present article is to determine the impact of selected exploitation factors, such as seasoning temperature, on adhesive bonds' strength. Therefore, adhesive joints prepared for tests were being seasoned for 3 months or 2 weeks in specified conditions. Seasoning conditions (time, temperature and number of seasoned bonds) together with designation of the seasoning variants are presented in Table 2 .

Table 2. Parameters of the adhesive joints seasoning process.

\begin{tabular}{|c|c|c|c|c|c|c|}
\hline \multirow{3}{*}{ 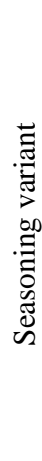 } & \multirow{3}{*}{ 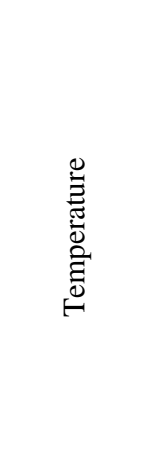 } & \multirow{3}{*}{ 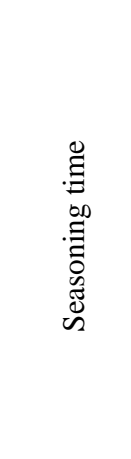 } & \multicolumn{4}{|c|}{$\begin{array}{c}\text { Number of adhesive joints } \\
\text { [pcs.] }\end{array}$} \\
\hline & & & \multicolumn{2}{|c|}{ Butt joints } & \multicolumn{2}{|c|}{$\begin{array}{l}\text { Half lap } \\
\text { joints }\end{array}$} \\
\hline & & & 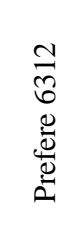 & 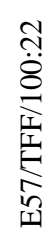 & 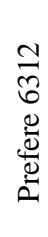 & 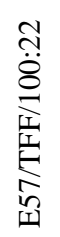 \\
\hline 1 & $-20^{\circ} \mathrm{C}$ & 3 months & 10 & 10 & 10 & 10 \\
\hline 2 & $6^{\circ} \mathrm{C}$ & 3 months & 10 & 10 & 10 & 10 \\
\hline 3 & $20^{\circ} \mathrm{C} \pm 1^{\circ} \mathrm{C}$ & 3 months & 10 & 10 & 10 & 10 \\
\hline 4 & $50^{\circ} \mathrm{C}$ & 2 weeks & 10 & 10 & 10 & 10 \\
\hline 5 & $80^{\circ} \mathrm{C}$ & 2 weeks & 10 & 10 & 10 & 10 \\
\hline 6 & $\begin{array}{c}-40{ }^{\circ} \mathrm{C} / 60 \\
{ }^{\circ} \mathrm{C}\end{array}$ & 2 months & 10 & 10 & 10 & 10 \\
\hline
\end{tabular}

To ensure the assumed conditions, it was necessary to use a few stands for seasoning samples. Samples intended for being seasoned at the lowest temperatures, i.e. $-20^{\circ} \mathrm{C}$ and $6^{\circ} \mathrm{C}$ were stored in a refrigerator-freezer. Some samples, according to Table 2, were left at room temperature equal to $20^{\circ} \mathrm{C} \pm 1^{\circ} \mathrm{C}$. A compact climaticthermal chamber ESPEC SH 661 was also used during the seasoning process. The climatic chamber enables for creating and, then, maintaining and monitoring climate, i.e. temperature and air humidity. According to the assumptions of the seasoning process described herein, the climatic chamber was pre-set for $50^{\circ} \mathrm{C}$ at relative air humidity $95 \%$, where samples were being seasoned for 2 weeks, as well as for $80^{\circ} \mathrm{C}$ at relative air humidity $80 \%$, where samples were left in such conditions also for 2 weeks. The last variant of the adhesive bonds seasoning was to expose them to cyclic heat loads. It was possible thanks to the use of a compact thermal shocks chamber ESPEC TSE - 1. The seasoning process conducted in a thermal shocks chamber gives information on an impact of sudden thermal changes on the adhesive bonds' strength. Adhesive-bonded joints subject to 3300 cycles of variable temperature, where one cycle consisted of 4 phases:

- hot chamber zone, time: 15 minutes, temperature: $60^{\circ}$,

- chamber change,

- stabilisation process,

- cold chamber zone, time: 15 minutes, temperature: 
$-40^{\circ}$.

The whole process lasted about 2 months.

\section{Test results and analysis}

After finishing the seasoning process, all adhesivebonded joints were subject to strength tests that were conducted in accordance with the standard PN-EN ISO 6892-1 [18], based on which tensile strength was determined.

\subsection{Adhesive-bonded butt joints strength}

The comparison of strength tests results of adhesivebonded butt joints, taking into consideration the adhesive type, was presented in Figure 5.

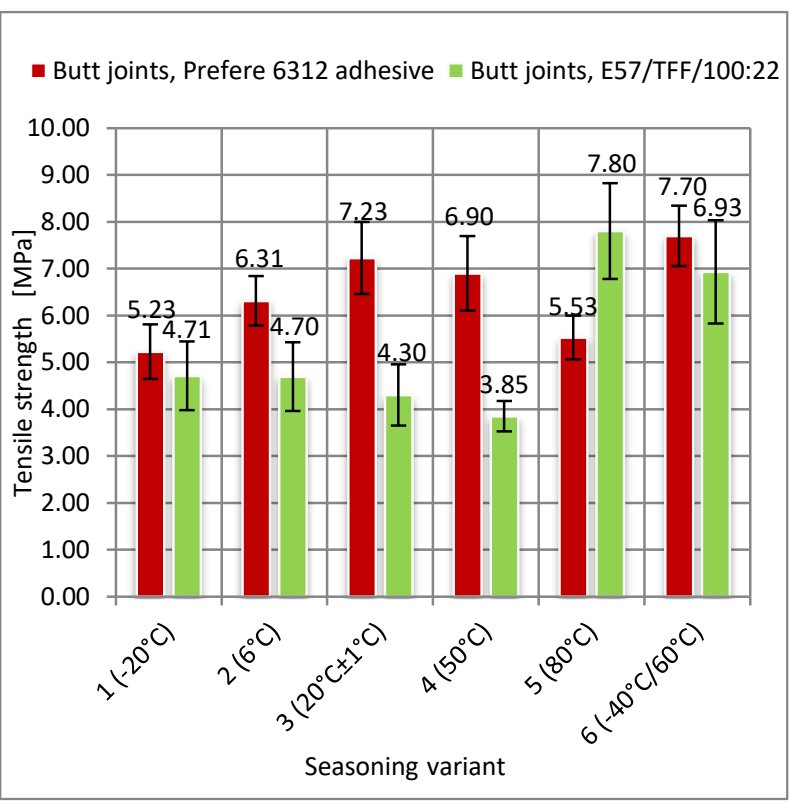

Fig. 5. Tensile strength of the adhesive-bonded butt joints.

Based on the comparative analysis of strength tests results of adhesive-bonded butt joints after different seasoning variants, it was observed that:

- the highest value of average tensile strength (7.70 $\mathrm{MPa}$ ) for the samples joined with the Prefere 6312 adhesive was obtained by the samples subject to the $6^{\text {th }}$ seasoning variant, i.e. cyclic thermal changes. The lowest value of average tensile strength (5.23 MPa) for the samples joined with the Prefere 6312 adhesive was obtained by the samples subject to the $1^{\text {st }}$ seasoning variant, i.e. at $-20^{\circ} \mathrm{C}$. The difference between the highest and the lowest values of tensile strength was about $32 \%$.

- in case of adhesive-bonded butt joints made with use of the E57/TFF/100:22 adhesive epoxide composition, the lowest tensile strength value was $3.85 \mathrm{MPa}$ and it concerned the $4^{\text {th }}$ seasoning variant. The highest tensile strength value $(7.80 \mathrm{MPa})$ was obtained for the $5^{\text {th }}$ seasoning variant. The difference between the highest and the lowest values of tensile strength was about $50.6 \%$.
- by comparing test results of the adhesive-bonded butt joints strength, it may be observed that the best results were obtained where the Prefere 6312 was used, apart from the $5^{\text {th }}$ seasoning variant $\left(\right.$ at $80^{\circ} \mathrm{C}$ ). In this case the adhesive joints made with use of the adhesive epoxide composition showed higher strength.

- standard deviation of all results is within a similar range and it amounts to about $12 \%$. It means that repeatability of tests results is high.

\subsection{Adhesive-bonded half-lap joints strength}

Strength test results of adhesive-bonded half lap joints, taking into consideration the adhesive type, were presented in Figure 6.

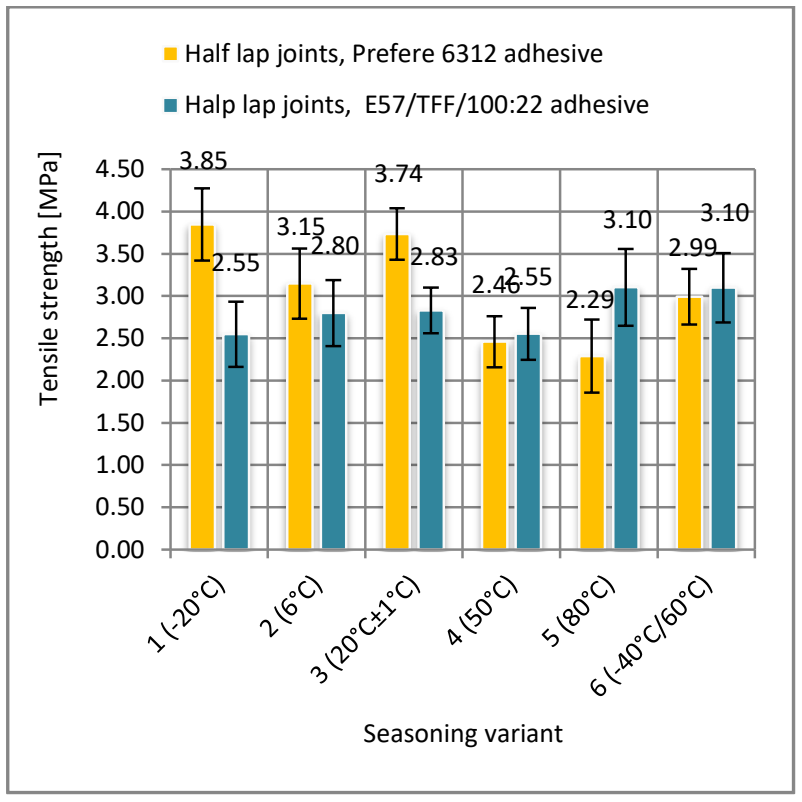

Fig. 6. Tensile strength of the adhesive-bonded half lap joints.

Based on a comparative analysis of strength tests results of adhesive-bonded half lap joints after different seasoning variants, it was observed that:

- the highest value of the average tensile strength $(3.85$ $\mathrm{MPa})$ for the samples joined with the Prefere 6312 adhesive was obtained by the samples subject to the $1^{\text {st }}$ seasoning variant, i.e. at $-20^{\circ} \mathrm{C}$. The lowest value of the average tensile strength $(2.29 \mathrm{MPa})$ for the samples joined with the Prefere 6312 adhesive was obtained by the samples subject to the $5^{\text {th }}$ seasoning variant, i.e. at $80^{\circ} \mathrm{C}$. The difference between the highest and the lowest values of tensile strength was about $41 \%$.

- in case of adhesive-bonded half lap joints made with use of the E57/TFF/100:22 adhesive epoxide composition, the lowest tensile strength value was 2.55 $\mathrm{MPa}$ and it concerned the $1^{\text {st }}$ and the $4^{\text {th }}$ seasoning variants. The highest tensile strength value (3.10 MPa) was obtained for the $5^{\text {th }}$ and the $6^{\text {th }}$ seasoning variants. The difference between the highest and the lowest values of tensile strength was about $17.7 \%$. 
Butt joints, Prefere 6312 adhesive

$\square$ Half lap joints, Prefere 6312 adhesive
Butt joints, E57/TFF/100:22

$\square$ Halp lap joints, E57/TFF/100:22 adhesive

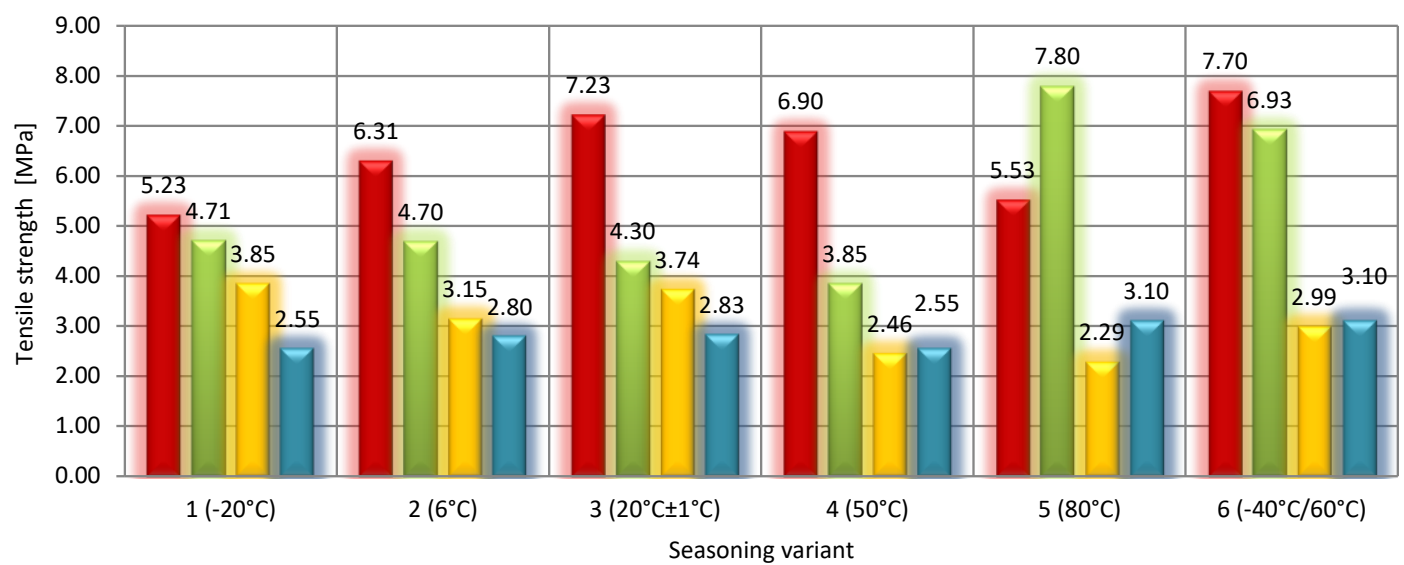

Fig. 7. Tensile strength of the adhesive-bonded joints of pine wood.

- When comparing test results of adhesive-bonded half lap joints, it may be observed that in case of the first 3 seasoning variants, joints made with use of the Prefere 6312 adhesive showed better results. In case of seasoning at higher temperatures and in variable conditions (variant 4-6), adhesive joints made with use of the E57/TFF/100:22 adhesive composition showed better results.

- The repeatability of test results in all cases is at comparable level.

\subsection{Comparative analysis of test results}

All strength test results were presented in Figure 7, through which it will be possible to assess the impact of seasoning conditions on strength of adhesive-bonded joints diverse in terms of the joint geometry and the type of adhesive.

Based on test results presented above, it may be observed that butt joints showed better strength properties, which enables for carrying heavier loads. Such joint structure is more advantageous than the halflap one for both types of adhesives in all seasoning variants. Considerable differences between strength tests results of adhesive-bonded half-lap joints and butt joints may be observed. However, the result distribution for both joint types is similar. In the majority of cases, joints made with use of Prefere 6312 are characterised by better results. As far as seasoning joints at $80^{\circ} \mathrm{C}$ is concerned, joints made with the epoxide composition E57/TFF/100:22 showed greater strength. However, when it comes to half lap joints, differences between results for both adhesives were less substantial than in case of butt joints. However, to state if the differences for both types of adhesives used herein are substantial, it was necessary to conduct statistical analysis of the obtained results.

In the first stage, with use of Shapiro-Wilk S-W normality test, an adjustment of empirical research of the analysed variables results to the normal distribution at the assumed significance level $\alpha=0.05$ was tested. The results were differentiated in terms of the analysed structure, material and exploitation factors. The normal distribution assumption was not proven for two groups (Table 3). Thus, non-parametric statistical tools were used for further analysis.

Table 3. Results of the normality tests of adhesive joints' strength.

\begin{tabular}{|c|c|c|c|c|}
\hline $\begin{array}{c}\text { Adhesive- } \\
\text { bonded joint } \\
\text { type }\end{array}$ & Adhesive & $\begin{array}{c}\text { Seasoning } \\
\text { variant }\end{array}$ & $\begin{array}{c}\text { Shapiro- } \\
\text { Wilk } \\
\text { statistics W }\end{array}$ & $\begin{array}{c}\text { Probability } \\
\text { level p }\end{array}$ \\
\hline Butt joints & E57/TFF/100:22 & $\begin{array}{c}\text { Variant 6 } \\
\left(-40^{\circ} \mathrm{C} / 60^{\circ} \mathrm{C}\right)\end{array}$ & 0.688129 & 0.001652 \\
\hline $\begin{array}{c}\text { Half lap } \\
\text { joints }\end{array}$ & Prefere 6312 & $\begin{array}{c}\text { Variant } 5 \\
\left(80^{\circ} \mathrm{C}\right)\end{array}$ & 0.784876 & 0.019675 \\
\hline
\end{tabular}

To state significant differences between groups, ANOVA was conducted. The post-hoc Tukey's test was used to designate homogenous groups. Their results are presented in Table 4. Based on statistical analyses results, it may be observed that in many cases joint groups are in the same homogenous groups, which means that differences occurring between the results are not significant at an assumed significance level. Also, in case of adhesive-bonded half lap joints made with use of adhesive epoxide composition, results of all seasoning variants are in a homogenous group (a), which means that the seasoning conditions of such joints do not have impact on their strength that is of much lower value than this of butt joints made with use of the same adhesive. The situation is similar in case of joints made with use of Prefere 6312.

\section{Summary and conclusions}

Based on the experimental tests and their analysis described herein, it was stated that:

- Wood is a very durable material and it rarely deforms. While conducting strength tests of adhesive-bonded joints, adhesive joints were damaged in all of them.

- The best type of joint structure for elements made of pine wood is butt joint.

- In numerous seasoning variants adhesive epoxide composition turned out to be as good as the Prefere 6312 adhesive dedicated to wood, which is much more expensive. 
- In case of joints made with use of E57/TFF/100:22, the joints seasoned at higher temperatures or those subject to variable thermal loads were much stronger.

- Both adhesives used in the tests show completely different behaviour at different temperatures, which proves that exploitation conditions have enormous impact on the adhesive characteristics and the adhesive bonds strength.

Table 4. Tukey's homogenous groups test results.

\begin{tabular}{|c|c|c|c|c|c|c|c|c|c|c|c|}
\hline \multirow{2}{*}{ : } & \multirow{2}{*}{ 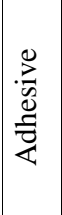 } & \multirow{2}{*}{ Seasoning variant } & \multirow{2}{*}{ 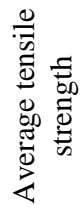 } & \multicolumn{8}{|c|}{ Homogenous groups } \\
\hline & & & & & & & & $\mathbf{f}$ & & $\mathbf{h}$ & i \\
\hline \multirow{12}{*}{ 苛 } & \multirow{6}{*}{$\begin{array}{l}\frac{1}{30} \\
0 \\
\frac{0}{0} \\
\frac{0}{2}\end{array}$} & Variant $1\left(-20^{\circ} \mathrm{C}\right)$ & 5.23 & & & & & * & & & \\
\hline & & Variant $2\left(6^{\circ} \mathrm{C}\right)$ & 6.31 & & & & & & 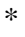 & $*$ & \\
\hline & & Variant $3\left(20^{\circ} \mathrm{C} \pm 1^{\circ} \mathrm{C}\right)$ & 7.23 & & & & & & & & $*$ \\
\hline & & Variant $4\left(50^{\circ} \mathrm{C}\right)$ & 6.90 & & & & & & & & $*$ \\
\hline & & Variant $5\left(80^{\circ} \mathrm{C}\right)$ & 5.53 & & & & & & N & & \\
\hline & & Variant $6\left(-40^{\circ} \mathrm{C} / 60^{\circ} \mathrm{C}\right)$ & 7.70 & & & & & & & & $*$ \\
\hline & \multirow{6}{*}{ 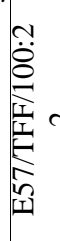 } & Variant $1\left(-20^{\circ} \mathrm{C}\right)$ & 4.71 & & & & * & * & & & \\
\hline & & Variant $2\left(6^{\circ} \mathrm{C}\right)$ & 4.70 & & & & * & * & & & \\
\hline & & Variant $3\left(20^{\circ} \mathrm{C} \pm 1^{\circ} \mathrm{C}\right)$ & 4.30 & & & & * & & & & \\
\hline & & Variant $4\left(50^{\circ} \mathrm{C}\right)$ & 3.85 & & & & & & & & \\
\hline & & Variant $5\left(80^{\circ} \mathrm{C}\right)$ & 7.80 & & & & & & & & * \\
\hline & & Variant $6\left(-40^{\circ} \mathrm{C} / 60^{\circ} \mathrm{C}\right)$ & 6.93 & & & & & & & & * \\
\hline \multirow{12}{*}{ 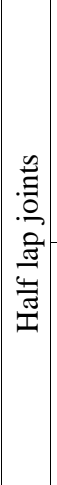 } & & Variant $1\left(-20^{\circ} \mathrm{C}\right)$ & 3.85 & & * : & : & & & & & \\
\hline & $\underset{2}{2}$ & Variant $2\left(6^{\circ} \mathrm{C}\right)$ & 3.15 & * & ** & & & & & & \\
\hline & 6 & Variant $3\left(20^{\circ} \mathrm{C} \pm 1^{\circ} \mathrm{C}\right)$ & 3.74 & & $* *$ & & & & & & \\
\hline & 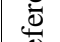 & Variant $4\left(50^{\circ} \mathrm{C}\right)$ & 2.46 & $*$ & & & & & & & \\
\hline & 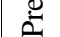 & Variant $5\left(80^{\circ} \mathrm{C}\right)$ & 2.29 & * & & & & & & & \\
\hline & & Variant $6\left(-40^{\circ} \mathrm{C} / 60^{\circ} \mathrm{C}\right)$ & 2.99 & $*$ & $*$ * & & & & & & \\
\hline & N & Variant $1\left(-20^{\circ} \mathrm{C}\right)$ & 2.55 & * & & & & & & & \\
\hline & $\ddot{8}$ & Variant $2\left(6^{\circ} \mathrm{C}\right)$ & 2.80 & * & $*$ & & & & & & \\
\hline & $\underset{1}{=}$ & Variant $3\left(20^{\circ} \mathrm{C} \pm 1^{\circ} \mathrm{C}\right)$ & 2.83 & * & * : & & & & & & \\
\hline & 空 & Variant $4\left(50^{\circ} \mathrm{C}\right)$ & 2.55 & * & & & & & & & \\
\hline & in & Variant $5\left(80^{\circ} \mathrm{C}\right)$ & 3.10 & $*$ & $*$ & & & & & & \\
\hline & I & Variant $6\left(-40^{\circ} \mathrm{C} / 60^{\circ} \mathrm{C}\right)$ & 3.10 & $*$ & $*$ & $*$ & & & & & \\
\hline
\end{tabular}

To conclude, it must be stated that the experimental tests results presented herein prove that adhesion is a very effective method of joining materials. However, there are several factors that impact the overall optimum strength of joined elements. They are, among others, structural, material, exploitation and technological factors. Moreover, the process of adhesion itself needs appropriate preparation, great precision and accuracy as even the smallest detail may influence the quality of the joint. Strength tests described in the present article showed substantial impact of selected structural, material and exploitation factors on the adhesive bonds' strength.

\section{References}

1. A. Higgins, Int. J. Adhes. Adhes. 20 (2000)

2. A.G. Magalhães, M.F.S.F. de Moura, J.P.M. Gonçalves, Int. J. Adhes. Adhes. 25, 313 (2005)

3. H. Moghadamzadeh, H. Rahimi, M. Asadollahzadeh A. R. Hemmati, Int. J. Adhes. Adhes. 31, 816 (2011)

4. C.D.M. Liljedahl, A.D. Crocomble, M.A. Wahab, I. A. Ashcroft, Int. J. Adhes. Adhes. 27, 505 (2007)

5. R.D.S.G. Camilho, M.F.S.F. de Moura, D.A. Ramantani, J. J.L. Morais, J.J.M.S. Domingues, Int. J. Adhes. Adhes. 29, 678 (2009)

6. A. Rudawska, Joint Strength Joining Composites with Adhesives (Lancaster: DEStech Publications, Inc., 2016)

7. L.D.R. Grant, R.D. Adams, L.F.M. da Silva, Int. J. Adhes. Adhes. 29, 535 (2009)

8. M. Müller, D. Herák, P. Valášek, Techn. Gazet. 20, 571 (2013)

9. M.F.S.F. de Moura, R. Daniaud, A. G. Magalhaes, Int. J. Adhes. Adhes. 26, 464 (2006)

10. L. Golio, M. Rossetto, E. Dragoni, Int. J. Adhes. Adhes. 28, 427 (2008)

11. M.A. Wahab, Joining composites with adhesives (Lancaster: DEStech Publications, Inc. 2016)

12. G.C. Mays, A.R. Hutchinson, Adhesives in civil engineering. (Cambridge University Press 2005)

13. J.R. Weitzenböck, D. McGeorge, Science and technology of bolt-adhesive joints. In Hybrid adhesive joints (Springer, Berlin, Heidelberg. 2011)

14. E. Serrano., Int. J. Adhes. Adhes. 24, (2004).

15. J.L. Paris, M. Schwarzkopf, X. Xiao, Wood Fiber Sci. 46 (2014)

16. R.D. Adams, Adhesive bonding: science, technology and applications. (Elsevier, 2005)

17. T. Jeliński, P. Cysewski, JCTR 13 (2016)

18. Metale -- Próba rozciągania -- Część 1: Metoda badania $w$ temperaturze pokojowej [Standard PNEN ISO 6892-1:2016-09] 